\title{
NADPRODUKCJA TALENTÓW W FORMATACH NA PRZYKŁADZIE MUZYCZNYCH TALENT SHOW
}

\author{
Abstract

\section{OVERPRODUCTION OF TALENT IN FORMATS BASED ON THE EXAMPLE OF MUSICAL TALENT SHOWS}

The subject of research are activities of television stations based on the adaptation of entertainment formats. An example of musical talent shows was used here as the most transparent shows of this type. The main goal is to show: dehumanized mechanisms and their effects in the form of overproduction of talents and viewer's opinions on this topic. The author looks for a solution that could prevent or mitigate this process (as a result of television activities within the production of formats). $\mathrm{He}$ finds the recipe in lean management philosophy. The key reflection of the text is the question about behind-the-scenes "life" as well as the motives and stages of such productions. The project was based on a review of literature and empirical research (quantitative and qualitative) in the form of: a survey, case study, in-depth and expert interview.

Key words: format, talent overproduction, talent, talent show, TV

\section{Wprowadzenie}

Warto sprecyzować, gdy zanotowano spadek zainteresowania tradycyjnymi mediami, a przy tym gwałtowne ruchy użytkowników polegające na migracji do środowiska Internetu, spowodowane przemianami technologicznymi, takimi jak m.in. cyfryzacja, tzw. starym mediom (książka, prasa, radio, telewizja etc.) nie pozostawiło to wyboru co do zmiany dotychczasowych zabiegów w ramach angażowania widza. Najważniejszą rolę zaczęły odgrywać w tej sytuacji agregatory treści związane z konwergencją, które umożliwiły nam dostęp do rozmaitych 
zasobów medialnych w dogodnym miejscu i czasie za pośrednictwem narzędzi mobilnych ${ }^{1}$.

W przeciwieństwie do innych tradycyjnych mediów, które od razu wdrażały nową formę funkcjonowania, telewizja przeszła do silnej ofensywy. Nastąpiła zmiana paradygmatu funkcjonowania $\mathrm{z}$ paleo- do neotelewizji, co $\mathrm{w}$ rezultacie spowodowało, iż użytkownicy tego medium zostali wyposażeni w narzędzia pozwalające na zmianę z biernego widza $w$ jego aktywną postać, decydującą, w jakim kierunku ma zmierzać telewizja i co ma sobą reprezentować. Znacznie poszerzył się przez to obszar audiowizualnej dokumentacji rzeczywistości, który znalazł ujście w programach typu reality i talent show - prawie każdy występ uczestnika rozpoczyna się już w tym momencie krótkim wideo (wraz z narracją lektorską) nakreślającym: życiorys występującego, jego zainteresowania, rozwój talentu oraz przeciwności losu, z jakimi być może mierzy się na co dzień.

W konsekwencji mamy obecnie do czynienia $\mathrm{z}$ formułą programów opartą na wątku dokumentacyjnym, realizowaną za pośrednictwem narzędzi zmierzających do: hybrydyzacji gatunkowej, formatyzacji widowisk i przerysowaniu zdarzeń łączących fikcję z życiem realnym².

Kwintesencją nowego paradygmatu neotelewizyjnego ${ }^{3}$ szybko okazały się dokonujące rozległej, międzynarodowej ekspansji programy na bazie formatu adaptacji zagranicznej wersji programu na zasadach macierzystej produkcji zagranicznej, według restrykcyjnych, spisanych w formie księgi wytycznych ${ }^{4}$, zwanych w branży "biblią formatu” czy inaczej „kartą formatu” - pilnie strzeżonych, objętych tajemnicą przedsiębiorstwa precyzyjnych porad ${ }^{5}$, jak opowiadać historie uczestników, by publiczność w nie uwierzyła ${ }^{6}$. Najpoważniejszy skutek powstawania niezliczonej liczby produkcji na kanwie biblii formatu zaczęła stanowić tzw. nadprodukcja talentów (podkreślona i podniesiona w dyskursie publicystycznym przez zwyciężczynię III odsłony Idola - Monikę Brodkę ${ }^{7}$ ), czyli proces „produkowania” zbyt dużej

${ }^{1} \mathrm{~J}$. Kreft, $W$ luce stabilności - poszukiwanie modelu biznesu starych mediów w cyfrowym środowisku, [w:] B. Nierenberg (red.), Zarządzanie reklama, Wydawnictwo Uniwersytetu Jagiellońskiego, Kraków 2015, s. 183-186.

${ }^{2}$ M. Przylipiak, U źródeł reality show, „Słupskie Prace Filologiczne. Seria Filologia Polska” 2004, nr 3, s. 193-195.

${ }^{3}$ Neotelewizja - obowiązujący do dziś paradygmat telewizyjny zmniejszający dystans z widzem i nadający mu liczne uprawnienia i atrybuty „władzy” mocodawcy i oceniającego. Za: F. Casetti, R. Odin, Od paleo- do neotelewizji. W perspektywie semiopragmatyki, [w:] A. Gwóźdź (red.), Po kinie? Audiowizualność w epoce przekaźników elektronicznych, Universitas, Kraków 1994.

${ }^{4}$ A. Moran, J. Malbon, Understanding the Global TV Format, Intellect Ltd., Portland 2006, s. 22.

${ }^{5}$ W. Sroka, M. Rajca, Ochrona tajemnicy przedsiębiorstwa na przykładzie formatu telewizyjnego. Wybrane zagadnienia, „Studenckie Zeszyty Naukowe” 2017, vol. XX, nr 34, s. 39-41.

${ }^{6} \mathrm{~K}$. Niesłony, Kultura polskiej twórczości audiowizualnej w tworzeniu krajowych adaptacji zagranicznych formatów telewizyjnych, „Pismo Humanistyczne” 2015, z. XIII, s. 512.

7 „Dziennik Zachodni”, Reaktywacja Idola? To nadprodukcja talentów!, https://tiny.pl/t9dpc. Cyt. za: 1NA1: Drzewiecka G., Gabi Drzewiecka vs Brodka, CGM 2017 (dostęp: 13.12.2018). 
liczby (w stosunku do liczby miejsc w branży rozrywkowej) pozornie gotowych na sukces uczestników popularnych reality i talent show.

Według przebadanych za pośrednictwem ankiety internetowej i papierowej zdeklarowanych widzów popularnych formatów rozrywkowych [203 - 76,8\% (155 - n) kobiet i 23,2\% (48 - n) mężczyzn] programów tego typu jest obecnie zbyt wiele (wykres 1). Wyników tych nie powinno się uogólniać ze względu na małą próbę badanych, jednakże ankietowani wskazują dość jednoznacznie na trend w obrębie adaptacji formatowej w naszym kraju.

Wykres 1. Adekwatność liczby programów muzycznych na rynku
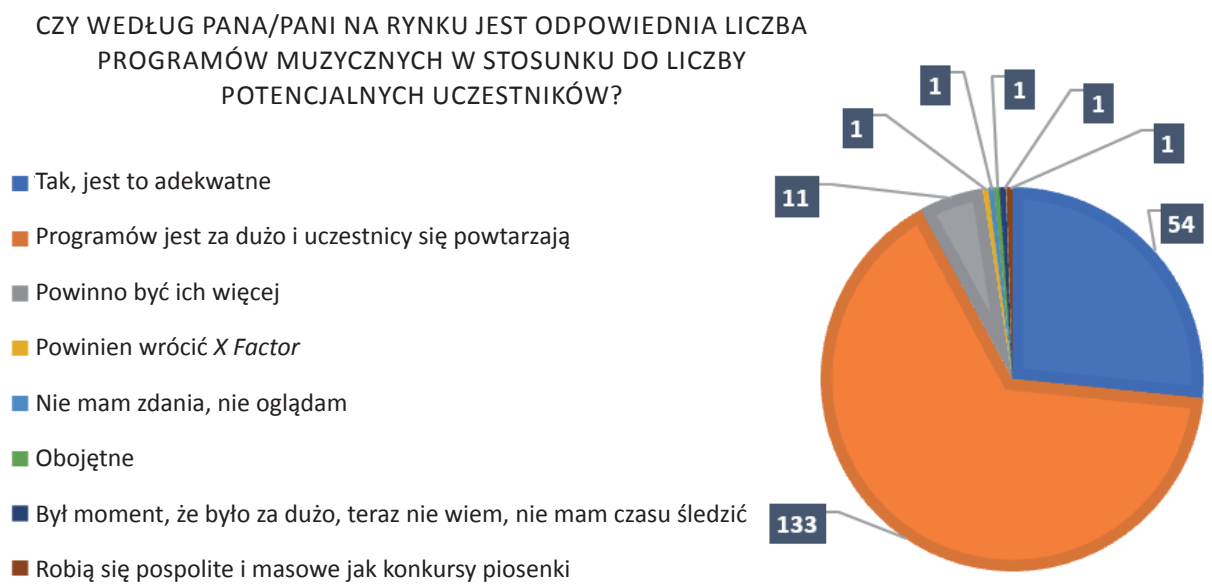

Źródło: badania własne.

Uczestnicy w dobie mnogości podobnej treści programowej zostali potraktowani jak tymczasowe „maskotki” na linii produkcyjnej, mające na celu przez jakiś czas zabawić i zaabsorbować sobą widza w celach maksymalizacji zysku dla stacji realizującej dane widowisko. Trzeba podkreślić, rynek muzyczny jest już przesycony debiutantami i nie ma zbyt wielu miejsc dla kolejnych osób. Obecnie daje się wejść do branży wyłącznie nielicznym ponadprzeciętnym osobowościom, jak twierdzi Monika Brodka ${ }^{8}$.

$\mathrm{Z}$ ponadprzeciętnych osobowości rodzą się natomiast finalnie kreacje wymyślone przez wielu ekspertów od marketingu. Są one jednak chwilowe, na potrzeby trwającej edycji show, co ma zapewnić wysoką oglądalność i silną markę danemu formatowi. Po emisji programu zostawia się takich uczestników samych sobie. Następnie tacy debiutanci mogą zostać przejęci przez „mejdżersów” (wielkie wytwórnie płytowe od „A do Z” kreujące ich wizerunek sceniczny i dyskografię), stając się

\footnotetext{
8 Tamże.
} 
pełnowartościowymi artystami lub po prostu celebrytami. Większość z nich wraca jednak do swojego dotychczasowego życia lub próbuje własnych sił dalej w kolejnych telewizyjnych produkcjach (m.in. Gosia Bernatowicz, Jarek Webber, Michalina Manios, Wojtek Ezzat, Paulina Lenda i wielu innych znakomitych artystów) w języku potocznym przyjęło się nazywać taki proces „skakaniem z programu do programu”.

Opracowanie to ma na celu ukazanie spektrum odhumanizowanych mechanizmów i ich skutku w postaci nadprodukcji talentów oraz przedstawienie opinii widzów na temat funkcjonowania tego unikatowego rodzaju widowisk medialnych. Niniejszy artykuł będzie swoistym „Projektem: Prawdą” przemysłu rozrywkowego, odkrywającym kulisy powstawania widowisk stworzonych według precyzyjnych wskazówek macierzystych produkcji.

Aby uwydatnić proces nadprodukcji talentów w formatach, kierowano się następującymi pytaniami badawczymi:

- Jak przekaz medialny jest odbierany przez widzów i co na to wpływa?

- Jaki wpływ na uczestnika ma udział w talent show?

- Jak wygląda zarządzanie uczestnikami show przez obsadę produkcji w trakcie trwania programu, a jak po jego zakończeniu?

- W jakim stopniu ingeruje się w decyzyjność uczestników?

- Jaką cenę musi „zapłacić” uczestnik za chwilę sławy w programie i czy istnieje sposób, aby zniwelować konsekwencje tego typu widowisk w postaci nadprodukcji talentów?

Badania nad nadprodukcją talentów, wyrażone poprzez: studia przypadku, ankietę oraz wywiady (pogłębione i rozmowę ekspercką), są próbą ułożenia mozaiki sądów na temat wnętrza tego typu organizacji medialnych, udowodnienia ogólnie panującego trendu w programach na kanwie formatu oraz znalezienia rozwiązania mającego na celu choć niewielkie zmniejszenie nadwyżki talentów w obrębie sektora rozrywkowego.

\section{Implikacje formatów rozrywkowych - przepis na sukces w dobie cyfrowej rozrywki}

Programy rozrywkowe, szczególnie te muzyczne, cieszą się od lat niesłabnącą popularnością. Dzieje się tak głównie za sprawą praktyk kulturowych widzów. Lubimy to, co szybkie, łatwe, przyjemne i niewymagające refleksji - Urszula Woźniak nazywa to „kulturą instant”. Według autorki każdy kraj posiada specyficzne uwarunkowania etniczno-społeczne. Zamiast konfrontować się z rzeczywistością i aktywnie wychodzić naprzeciw wyzwaniom, polski widz chętnie z bezpiecznej odległości

9 Metafora odnośnie do talent show. Cyt. za: M. Szczygieł, Projekt: Prawda, Fundacja Instytutu Reportażu, Warszawa 2016. 
obserwuje widowisko i to, jak uczestnicy rozmaitych konkursów, zawodów czy teleturniejów konkurują między sobą, jak zmagają się z trudnościami i odnoszą sukcesy. Często się przy tym także dowartościowuje albo przeciwnie, przenosi w bajkowy świat marzeń ${ }^{10}$.

Doskonałym rozwiązaniem i co do wypełnienia luki w oczekiwaniach widzów, i pod względem budżetowym okazała się adaptacja zagranicznych formatów. Całość tego typu show jest do takiego stopnia przygotowana, że jeszcze przed rozpoczęciem realizacji producent wie, kogo ma zatrudnić, jaki zgromadzić budżet i jakie może osiągnąć wyniki oglądalności przygotowywanego przedsięwzięcia, co szalenie ułatwia proces wdrożenia nowego widowiska i decyduje o tym, iż bardziej opłaca się adaptować obcy pomysł niż inwestować w autorskie, lokalne produkcje, w których prawdopodobieństwo porażki jest znacznie wyższe ${ }^{11}$. Z perspektywy ekonomicznej można mówić o tzw. handlu formatami, gdzie poniesiona inwestycja zakupu formatu na określonej licencji zapewnia pewne zyski z oszacowanym nakładem, a nawet oczekiwanym zwrotem z inwestycji. Również role pomysłodawcy, dystrybutora i nadawcy są już z góry usankcjonowane i zabezpieczone, nad wszystkim zaś czuwa organizacja zrzeszająca tego typu podmioty twórcze - Format Recognition and Protection Association (FRAPA) ${ }^{12}$.

Jak podaje w opracowaniu Maciej Mrozowski, już w 2010 roku mieliśmy do czynienia $\mathrm{z}$ trendem, a każda $\mathrm{z}$ rodzimych stacji posiadała $\mathrm{w}$ ofercie programowej po kilkanaście formatów - od seriali przez teleturnieje aż po talent show (TVP - 14, TVN - 32, a Polsat aż 37) ${ }^{13}$.

\subsection{Format - aspekty prawne, semantyczne, kulturowe}

Samo pojęcie formatu wykreowane zostało przez wąski sektor producentów medialnych i miało ułatwić komunikacje wewnętrzną, w rezultacie sprawiło jednak ogromne trudności z prostą transpozycją tego słowa: zarówno w znaczeniu potocznym, jak i na gruncie prawnym. W ustawodawstwie (międzynarodowym i krajowym) brak jednoznacznej definicji tego terminu, a w mowie potocznej mylony jest on często po prostu ze zwykłym programem ${ }^{14}$. Przez słowo format powinno się rozumieć natomiast - według Z. Pinkalskiego - w dużym uproszczeniu: „szkielet

${ }^{10}$ U. Woźniak, Przyjemność „instant” $w$ formatach rozrywkowych $z$ perspektywy procesów poznawczych i emocjonalnych, "Annales Universitatis Paedagogicae Cracoviensis: Studia de Cultura” 2013, vol. V, s. 189-190.

${ }^{11}$ K. Niesłony, Kultura polskiej twórczości..., dz. cyt., s. 514. Cyt. za: I. Cury, Directing and Producing for Television: A Format Approach, Focal Press, Amsterdam 2007.

${ }_{12}$ M. Wawer, Przemiany modelu handlu formatami telewizyjnymi w wymiarze kulturowym i ekonomicznym, „Zarządzanie Mediami” 2020, t. 8, nr 1, s. 27-29.

${ }_{13}$ M. Mrozowski, Spectator in spectaculum. Ukryte osobowości programów telewizyjnych TVP1, TVP2, TVN, Polsat, „Studia Medioznawcze” 2010, nr 1 (40), s. 22.

${ }^{14}$ Z. Pinkalski, Prawna ochrona formatów telewizyjnych, Wolters Kluwer, Kraków 2015, s. 18-19. 
programu, dzięki któremu możliwe jest tworzenie kolejnych serii oraz regionalnych wersji programu (adaptacji)"15.

W literaturze brakuje spójnej definicji, która ujmowałaby wieloaspektowość pojęcia formatu z perspektywy: prawnej, medioznawczej i społeczno-kulturowej. Istnieje zatem kilkanaście nieco odmiennych określeń. Podnosi się m.in., że: „to ogólna koncepcja serii programów o różnym charakterze: teleturniejów, quizów czy widowisk” 16 lub np. „zbiór niezmiennych cech i elementów danego programu, $\mathrm{w}$ ramach których jednorazowo produkowane są inne elementy dopasowywane do pojedynczego epizodu"17.

Mimo ekspansji, z jaką formaty podbiły rynek mediów, z chwilą „wejścia na rynek" sprawiły problemy nie tylko prawno-semantyczne, ale także kulturowe: natury pragmatycznej i gatunkowej. Od dłuższego czasu przez wielu utożsamiane są bowiem ze standardową licencją, mimo że tak naprawdę sama licencja to jedynie forma umowy pozwalającej na produkowanie programów telewizyjnych, niekoniecznie ingerująca tak stanowczo w proces funkcjonowania danego wytworu oraz zarządzania jej zasobami. Jest to forma manipulacji odbiorcą i hipokryzji ze strony producenckiej, gdyż pod fasadą takiego nazewnictwa wolnego od podejrzeń wyreżyserowania tworzy się przekaz oparty według precyzyjnych wskazówek właścicieli macierzystego formatu. Licencja jako taka, ustanawiana umową, jest absolutnie jawna i zawiera zasady korzystania z pomysłu na program, jasno określone pola jego eksploatacji i warunki zapożyczenia.

Nie jest tak jednakże $z$ formatem, który zresztą sam ulega licencjonowaniu i bezpośrednio, pod groźbą sankcji, narzuca formy adaptacji swojego produktu w danym kraju - precyzując osobowość i cechy, jakimi powinien się odznaczać dany juror w panelu oraz odpowiadając: jakie doświadczenia powinien posiadać zwycięzca lub jaki jest przekrój wiekowy uczestników danej odsłony? oraz wiele innych wytycznych zależnych od konkretnego formatu oraz edycji show ${ }^{18}$.

Jak przedstawia Kamil Niesłony:

Szczegółowość biblii produkcyjnej różni się w każdym z przypadków, ale można wymienić te opisy, które pojawiają się najczęściej, a są to: opis charakteru audycji, zasady gry, scenariusze odcinków, informacje o potencjalnych odbiorcach, sugerowane godziny emisji, plany produkcyjne i techniczne (w tym projekty: scenografii, światła, grafiki, muzyki, montażu), odcinki pilotażowe, odcinki formatu już zrealizowane w innych krajach, wyniki oglądalności z innych krajów, hasła promocyjne i materiały marketingowe ${ }^{19}$.

15 Tamże.

16 J. Barta, M. Markiewicz, Prawo autorskie, Wolters Kluwer, Warszawa 2010, s. 43.

17 A. Moran, Copycat Television: Globalization Program Formats and Cultural Identity, Luton University Press, Luton 1998, s. 13.

18 M. Załucki, Licencja na używanie znaku towarowego. Studium prawnoporównawcze, Oficyna, Warszawa 2008, s. 37-38.

19 K. Niesłony, Kultura polskiej twórczości..., dz. cyt., s. 514. Cyt. za: Medioskop, Format telewizyjny, https://tiny.pl/t9cnb (dostęp: 30.12.2018). 
Samo pojęcie formatu nie jest jednak „wymysłem” postmodernistycznym, lecz posiada długą tradycję w historii telewizji i jest $\mathrm{z}$ nią ściśle powiązane, całkowicie poza telewizją mimo wszystko nie ma racji bytu i tylko w takim kontekście mamy prawo go używać. Określenia „format radiowy” czy „format w Internecie” to zdecydowane nadużycia określenia formatu w kontekście semantycznym, niejednokrotnie występujące jednak w literaturze. W każdym razie takich formatów jeszcze się nie doczekaliśmy i słowo "format” z perspektywy medioznawczej jest zarezerwowane tylko i wyłącznie dla przestrzeni telewizyjnej.

W chwili swojego triumfu format rozrywkowy sprawił także wspomniany olbrzymi problem z perspektywy medioznawczej, z jakiej strony go ulokować. Często mylony z gatunkiem, tak naprawdę nim nie będąc, a rozmaite typy widowisk zawierając - od dokumentu, przez seriale i reality show do jego najbardziej topowej wersji, czyli talent show. Ostatecznie format znalazł się poza gatunkiem, zmierzając bardziej ku usankcjonowanej formie współpracy między tworzącymi koncept producentami a stacją telewizyjną zapożyczającą go ${ }^{20}$. Według autora publikacji, najlepiej określałby go:

Gotowy produkt medialny w formie recepty prawno-kulturowej na sukces rynkowy w telewizyjnym przemyśle rozrywkowym, stworzony przez producentów jednego kraju, ulegający adaptacji w różnym środowisku kulturowym (precyzując przy tym spisane $\mathrm{w}$ formie księgi: plan, zasady i etapy widowiska, grafikę, muzykę, plan scenografii oraz przykładowe realizacje konceptu wraz z przewidywanym wynikiem oglądalności oraz wzorcem uczestników oraz jurorów).

\subsection{Zasady tworzenia show na kanwie formatu}

Kluczową kwestię stanowi jednakże nadmieniona adaptacja formatu w innym kraju, która jest przystosowaniem nowej formy programowej w środowisku prawnym i kulturowym obcego (korzystającego $\mathrm{z}$ licencji) kraju ${ }^{21}$. Adaptacja formatu nie dopuszcza bowiem jakichkolwiek samodzielnych zmian poza tymi, które są konieczne w konfrontacji z macierzystą formułą po konsultacji z tzw. flying producer. Za pośrednictwem wymienionej funkcji łącznika pomiędzy produkcjami („latającego producenta") mogliśmy zaobserwować w perspektywie globalnej takie zmiany, jak choćby modyfikacja nazwy odpowiednika $X$ Factora w Rosji ${ }^{22}$. Dopuszczono tam bowiem zmianę „X” na „A” z racji uznania za królową rosyjskiego przemysłu

${ }^{20}$ G. Ptaszek, W stronę bezgatunkowości mediów? O funkcji gatunków medialnych w procesie odbioru, [w:] W. Godzic, A. Kozieł, J. Szylko-Kwas (red.), Gatunki i formaty we współczesnych mediach, Poltext, Kraków 2015, s. 37-41.

${ }^{21}$ J. Mikucki, Format programu telewizyjnego a normy kulturowe. Przypadek reality show Rolnik szuka żony, „Naukowy Przegląd Dziennikarski” 2016, nr 1, s. 70-73.

${ }^{22}$ K. Niesłony, Kultura polskiej twórczości..., dz. cyt., s. 517-519. Cyt. za: K. Perkowska, Problemy produkcji telewizyjnych formatów na podstawie przykładów audycji zrealizowanych $w$ Polsce, praca magisterska (praca niepublikowana), dostępna w PWSFTViT, Łódź 2012, s. 54-75. 
muzycznego Ałły Pugaczowej ${ }^{23}$. Tego samego mogliśmy doświadczyć na rynku polskim, gdzie TVP udało się uzyskać zgodę na to, by w programie Bitwa na gło$s y$ wprowadzić panel jurorski z powodu kulturowych przyzwyczajeń Polaków do obecności jurorów w tego typu show ${ }^{24}$. Takie zabiegi to właśnie typowe przykłady i wzorzec adaptowania formatu w innych krajach o odmiennym kręgu społeczno-kulturowym.

Najważniejszym dylematem pozostaje jednak to, w jaki sposób „podać” widzowi tak ściśle wykreowany produkt, by ten nie zorientował się co do zamiarów stacji telewizyjnych, dotyczących bezrefleksyjnej konsumpcji treści. Tu na ratunek przychodzi "narzędzie” zwane realizmem, czasem nawet określane mianem nadrealizmu. Realizm gatunkowy pozwala wczuć się widzowi w przedstawiony świat - baśniowy, ale jednak możliwy do spełnienia. Realizm w telewizji według Dominica Strinatiego (powołującego się na Davida Harveya) to nic innego, jak dominacja zabawy i relacji międzyludzkich nad treścią i znaczeniem danego przekazu ${ }^{25}$.

Prezentuje się w ten sposób uczestników z pozoru zwyczajnych i skromnych, ale też odważnych w sięganiu po swe niespełnione marzenia, co w literaturze opisuje się jako strategie reprezentacji w akcie komunikacji (dany element oddaje charakter wycinka znanej powszechnie rzeczywistości) ${ }^{26}$. Głównie dlatego w czasie jednej edycji pojawia się w rezultacie: ofiara hejtu, osoba pewna siebie, otyły, gaduła czy przedstawiciel mniejszości. W praktyce zwiększa to szansę na poszerzenie audytorium danego programu.

Brane pod uwagę są nawet - zgłaszane mailowo, telefonicznie, za pośrednictwem aplikacji czy fanpageów - zażalenia widzów, które stopniowo zaspokaja się licznymi zabiegami producentów, ukrytymi pod płaszczykiem przyjaznego kontaktu z widzami i produkowania programów zgodnie ze standardami Rady Etyki Mediów. Proces ten widoczny jest najbardziej podczas doboru uczestników kolejnych edycji, co finalnie wartościuje ich niestety i stawia w kategorii produktowej ${ }^{27}$. Obecnie to pośrednio widz dyktuje warunki, co ma się zdarzyć na ekranie, dlatego też właśnie według jego upodobań realizowane są liczne zabiegi. Oglądający szuka urzeczywistnienia własnych marzeń w kimś realnym jego pokroju. W badaniach dotyczących wpływu telewizji w kontekście reakcji widzów nazwiemy to konstruktem interakcji paraspołecznej (parasocial interaction), która nada ostateczny kształt rozrywce widza ${ }^{28}$ podczas rozmaitych odmian channel switchingu, czyli potocznie zwanej czynności „skakania po kanałach” (zapping - ucieczka od reklam, flipping

${ }^{23}$ Faktor Ałly Pugaczow, https://dziendobry.tvn.pl/a/faktor-ally-pugaczowej (dostęp: 31.12.2018).

${ }^{24}$ K. Niesłony, Kultura polskiej twórczości..., dz. cyt., s. 519-520.

${ }_{25}$ D. Strinati, Wprowadzenie do kultury popularnej, tłum. W.J. Burszta, Zysk i S-ka, Poznań 1998, s. 180.

${ }^{26}$ A. Burn, D. Parker, Analysing Media Texts, Bloomsbury Academic, London-New York 2003, s. 6.

${ }^{27}$ A. Ogonowska, Edukacja medialna: ziemia wciąż nieznana?, „Kultura, Społeczeństwo, Edukacja” 2012, nr 1, s. 182-184.

${ }^{28}$ U. Woźniak, Przyjemność „instant” w formatach..., dz. cyt., s. 192-193. 
- zmiana kanału bez powodu i grazzing - brak zdecydowania na konkretną treść emitowaną w tym samym czasie na różnych kanałach ${ }^{29}$.

Tomasz Orłowski dostrzega rozmaite czynniki uwzględniające praktyki kulturowe odbiorców. Przede wszystkim w programie muszą znaleźć się osoby zdolne, o nadzwyczajnym talencie, mocnym wizerunku i niezwykłej osobowości, lecz na potrzeby wzbudzenia u widza innych emocji, niż tylko zachwyt, pojawiają się także osoby godne politowania i wywołujące u niego szeroki uśmiech. W pierwszych zmaganiach - jak pisze Orłowski - odpadają głównie najsłabsi, ci, których uczestnictwo zostało zaakceptowane na zasadzie „ludzkiej karykatury” czy przez głupotę, mającą za zadanie rozbawić widza. Określa on ten zabieg „mięsem armatnim”. Następnym etapem działań są wszelkiego rodzaju badania - eksperci analizują poparcie internautów, czytają komentarze i przeprowadzają setki głosowań ${ }^{30}$.

Niebagatelną rolę odgrywać tu muszą także jurorzy, którzy mają za zadanie znaleźć „ludzi niezwykłych”, działając jako cichy manipulator wrażeń widza ${ }^{31}$. Kiedy już w wyniku wymienionych czynności zostaną wyłonieni „pewniacy” ${ }^{2}$, to spośród nich telewizja wybierze zwycięzcę zgodnego z profilem biblii produkcyjnej.

\subsection{Redefinicja talentu}

W konsekwencji także samo brzmienie talent (show) ma już nieco inny wydźwięk niż jeszcze kilka lat wstecz. Przedstawione dopasowywanie oferty programowej doprowadziło do całkowitej redefinicji pojęcia talentu w obrębie przemysłu medialnego. Talent, który kojarzony był jako: „Wrodzona umiejętność (...) predyspozycje w dziedzinie intelektualnej lub ruchowej, (...) które w sposób wyjątkowy przyczyniają się do realizacji strategii organizacji i wyróżniają się ponadprzeciętnym potencjałem do dalszego rozwoju" ${ }^{33}$, sporo zyskał na wartości semantycznej, natomiast zdecydowanie stracił w kwestii etycznej. Z reguły „niczym nieskażony”, naturalny walor, którego nie posiadał bowiem każdy, stał się zestawem cech absolutnie $\mathrm{w}$ większości nabywanych. Autor publikacji w wyniku rozmowy z jednym z uczestników popularnego formatu, na potrzeby pracy dyplomowej ${ }^{34}$ oraz licznych obserwacji ogromnej liczby talent show, zdecydował, iż można zaklasyfikować talent już nie tylko jako samą umiejętność, lecz wypadkową kilku cech, takich jak: umiejętności specjalistyczne (wokalne, taneczne itp.), ponadprzeciętną osobowość i urodę

29 P.T. Nowakowski, Fast food dla mózgu, czyli telewizja i okolice, Maternus Media, Tychy 2002, s. 9.

${ }_{30}$ T. Orłowski, Jak działaja media - na przykładzie talent-show. TAK jestem na Nie, http://linkd. pl/kk9 (dostęp: 27.05.2019).

31 A. Jupowicz-Ginalska, Jurorem być, czyli rzecz o komisjach sędziowskich w programach talent show, „Rocznik Bibliologiczno-Prasoznawczy” 2012, nr 4 (15), z. 2, s. 157.

${ }_{32}$ T. Orłowski, Jak działaja media..., dz. cyt.

${ }^{33}$ Czym jest talent?, https://hrht.pl/czym-jest-talent/ (dostęp: 30.12.2018).

${ }^{34}$ Ł. Flak, Zarządzanie wizerunkiem uczestników muzycznych talent show na wybranych przykładach, Kraków 2017 (praca magisterska niepublikowana), s. 96-100. 
oraz przede wszystkim oryginalną historię z życia (storytelling ${ }^{35}$ ). Szczególny akcent stawiany jest obecnie na czynnik ostatni, który zdecydowanie predestynuje lub całkowicie przekreśla szanse zwycięstwa. Zdecydowana przewaga występów w talent show jest poprzedzana „chwytającą za serce” historią, czego przykładem może być sytuacja związana z wyższością historii nad resztą czynników, jaką idealnie odzwierciedla los uczestnika pochodzącego z rodziny o niskim statusie materialnym - Patryka Grudowicza, który dzięki udziale w Top Model zyskał poniekąd wbrew regulaminowi ${ }^{36}$ nowe uzębienie podczas trwania szóstej edycji, dzięki czemu mógł rywalizować z resztą uczestników i ostatecznie wygrać program ${ }^{37}$.

\subsection{Etyka vs. biznes}

Przedstawione techniki świadczą jasno o problemie etycznym, jaki występuje w obrębie widowisk. Tradycyjne pojęcie etyki, etyki w mediach, zatraciło więc swój pierwotny sens, a sam człowiek służy już osiąganiu celów, zgodnie z regułami wyłożonymi przez Markiza de Sade, według którego naczelną kwestią powinno być podtrzymywanie progresu i ciągłe podbijanie stawki za wszelką cenę $e^{38}$. Przywołajmy więc Piotra Misiło, który stwierdza, że mimo rozmaitych aktów normatywnych (dotyczących reklamy, dziennikarstwa i przedstawiania informacji) regulujących kwestie etyki w mediach, nadal istnieje przyzwolenie na powielanie kłamstwa, zatajanie wiedzy przed opinią publiczną, a sama informacja staje się cennym towarem, dlatego z różnych powodów - głównie natury ludzkiej i pobudek ekonomicznych - zostaje ona zmanipulowana ${ }^{39}$.

Etyka w mediach (a właściwie jej brak) ze względu na masowe oddziaływanie mediów, oddziaływanie absolutnie globalne, urosła do rangi ponadwyznaniowej religii świadomej manipulacji. (...) Nieetyczność w mediach, w polskich mediach, stała się zjawiskiem tak powszechnym, że czyny nieetyczne stały się częścią medialnej codzienności $(. . .)^{40}$.

35 Storytelling - koncepcja tworzenia historii wyjaśniająca wydarzenia za pośrednictwem narracji prawdziwych, fikcyjnych lub ich kombinacji. Używana do zwiększenia lojalności konsumentów poprzez rozrywkę lub emocjonalny związek. Za: Słowniczek TVN, https://www.tvnmedia.pl/poradnik/slowniczek?tab=16 (dostęp: 1.07.2019).

${ }^{36}$ Warunki uczestnictwa: 4. H - „zobowiązany do niezmieniania przez cały czas trwania Konkursu i Audycji swojego wizerunku i wyglądu”. Cyt. za: Regulamin konkursu organizowanego w ramach audycji „Top Model”- sezon 7, https://cutt.ly/hwuoLBV (dostęp: 26.07.2019).

${ }_{37}$ G. Czernecka, Top Model Polska 6 - Patryk Grudowicz już ma nowy uśmiech!, https://cutt.ly/ jwuhIm5 (dostęp: 3.01.2019).

${ }_{38}$ P. Misiło, O etyce w polskich mediach - ethics mortuus, http://www.misilo.pl/images/pdf/ Etyka_w_polskich_mediach_ethics_mortuus.pdf (dostęp: 31.12.2019); M. Delon, Introduction, Édition Gallimard: Bibliothèque de la Pléiade, Paris 1990, s. LII; M. de Sade, Histoire de Juliette, Rome 1797, s. 1261.

${ }^{39}$ P. Misiło, O etyce w polskich mediach..., dz. cyt., s. 9.

${ }^{40}$ Tamże, s. 10-11. 
Stacje telewizyjne maksymalizują zyski z nowej formy angażowania widzów bez względu na konsekwencje, korzystając z bardzo ogólnej treści aktów etycznych w polskim prawodawstwie i braku bezpośredniego odniesienia do kwestii produkowania programów na tzw. karcie formatu oraz zasad zarządzania zasobami ludzkimi w ich obrębie. W literaturze naukowej dotyczącej dyscypliny nauk o komunikacji społecznej i mediów brakuje głęboko osadzonego i refleksyjnego opracowania na podnoszony w artykule temat formatów rozrywkowych i „nadprodukowania" na jego kanwie talentów.

Ograniczenie problemów w postaci nadprodukcji talentów jest natomiast jak najbardziej możliwe (fabryka Toyoty w obrębie nadprodukcji zastosowała m.in. koncepcje lean manufacturing, zakładającą eliminacje marnotrawstwa zasobów w ramach tzw. odchudzonego zarządzania ${ }^{41}$ ), lecz owa nadwyżka talentów wpisana jest z góry w konsekwencje powstawania widowisk, zaś ich liczba przekłada się dla stacji na czysty zysk, z którego raczej żadna stacja nie chciałaby finalnie całkowicie zrezygnować. Zjawiska w obrębie sfery telewizyjnej związane $\mathrm{z}$ formatyzacją, w konsekwencji prowadzące do nadprodukcji uzdolnionych osób, docelowo dążą więc do masowej konsumpcji treści programowej, co ma bezpośrednie przełożenie w udziałach na rynku telewizyjnym, generujące olbrzymie kwoty z tytułu reklam i lokowania produktu.

\section{Muzyczne programy rozrywkowe w Polsce}

Jak można zatem zauważyć, nie dość, że format zrewolucjonizował rynek audiowizualny i znalazł dla siebie idealne miejsce pomiędzy wachlarzem cyfrowych rozrywek, to spowodował również uśpienie czujności użytkowników, którzy głównego zagrożenia dla swojej prywatności i bezpieczeństwa zaczęli upatrywać w nowych mediach. Telewizja, wykorzystując to zjawisko, zaczęła przyglądać się nowym praktykom kulturowym i układać skrzętnie ukryty plan technicyzacji widowisk, służący maksymalizacji zysków.

Mimo ogromnej mnogości produkcji opartych na nowej recepcie sukcesu rynkowego (reality show: Agent - 2000 rok oraz Big Brother - 2001, talent show: Droga do gwiazd - rok 2001, Idol - 2002 etc.), zwanej formatem, autor zdecydował jednak, iż trend nadprodukcji talentów jako dominującej konsekwencji nowego paradygmatu telewizji ukaże za pośrednictwem popularnych muzycznych talent show, ponieważ są one najbardziej transparentnymi programami posiadającymi w sobie wachlarz technik manipulacji widzem i uczestnikiem.

${ }^{41}$ J.P. Womack, D.T. Jones, Lean thinking - szczupłe myślenie. Eliminowanie marnotrawstwa i tworzenie wartości w przedsiębiorstwie, Prodpress, Wrocław 2008. 


\subsection{Systematyzacja muzycznych talent show}

Specyficzny twór medialny, jakim są programy rozrywkowe wykorzystujące kulturę muzyczną jako motyw przewodni show, autor już w 2017 roku w swojej pracy licencjackiej ${ }^{42}$ określił jako tzw. muzyczne talent show. Śledząc na bieżąco dyskurs naukowy, tym samym tropem podążają również inni badacze, używając i popularyzując w swoich pracach nawet akronim pojęcia - MTS ${ }^{43}$.

Autor publikacji dokonał pewnej systematyzacji widowisk tego typu, dlatego iż będący głównym przedmiotem analizy format (i formy gatunkowe, które stały się jego częścią) ma za sobą bardzo niejasną historię podpartą bogatą literaturą. $\mathrm{W}$ ostatnich latach pojawiło się bowiem wiele programów typu talent show, mających „z założenia” wypromować zdolnych muzyków - od jakiegoś czasu to jedna z najpopularniejszych metod zaistnienia i zabłyśnięcia w światku muzycznym. Jeśli chodzi o Polskę, pionierem był - jeszcze wtedy nienazywany typowym talent show - program telewizji TVP2 emitowany od listopada 1993 roku, czyli Szansa na sukces, będący telewizyjną formą karaoke. Silnie wtedy utożsamiany z konkursem Wojciech Mann pociągał za tasiemkę z numerem, pod którym to krył się utwór rozszyfrowywany przez gwiazdę odcinka.

Niezachwianej pozycji Szansy... zaczęła zagrażać dopiero w 2001 roku telewizja TVN pierwszym muzycznym talent show opartym na zagranicznym formacie Droga do gwiazd, którą prowadził Zbigniew Wodecki ${ }^{44}$. Mimo że wiele opracowań rozpoczyna historię talent show od Idola, to właśnie Droga do gwiazd była protoplastką w tej materii. Zwycięzcą pierwszej jej edycji talent show został Jarek Webber, drugiej - Cezary Klimczak, trzeciej - zespół Albo Nie, natomiast czwartej Emilia Majcherczyk. Jak można zatem zaobserwować, nawet triumf nie zapewniał pozycji lidera na rynku muzycznym.

Wracając do Idola, zrewolucjonizował on rynek mediów w tamtym czasie, generując niebagatelne zyski dla stacji. Nadał on nowy sznyt telewizyjnym konkursom wokalnym, wprowadzając niespotykane dotąd w naszym kraju zasady, regulaminy i łącząc w sobie kilka form gatunkowych oraz etapów: castingi a cappella, teatr, etap klubowy i odcinki na żywo. Zwycięzca programu otrzymywał nagrodę pieniężną, ale i - jakże upragniony jak na tamte czasy - kontrakt płytowy. Do odcinków na żywo o losie uczestników decydowali obsadzeni w roli jurorów eksperci, następnie rolę „dyrygenta” (zgodnie z neotelewizyjnym przymusem) kariery młodych ludzi przejmowali widzowie show głosujący drogą SMS-ową.

${ }^{42}$ Ł. Flak, Zarządzanie wizerunkiem uczestników..., dz. cyt., s. 6.

${ }^{43}$ B. Jabłońska, Dziecko - media - muzyka: fenomen muzycznych TV talent show, [w:] M. Bogunia-Borowska (red.), Współczesny świat dziecka. Media i konsumpcja, Wydawnictwo Uniwersytetu Jagiellońskiego, Kraków 2019, s. 322.

${ }_{44}$ Anonim, Droga do gwiazd, http://zloteprzeboje.tuba.pl/zloteprzeboje/56,101972,8903277, droga-do-gwiazd-twoja-droga-dogwiazd,,2.html (dostęp: 27.05.2019). 
Celem programu było znalezienie niepowtarzalnych osobowości na polskiej scenie muzycznej, a ogromny w tym udział mieli wspomniani jurorzy wybierani na zasadzie autorytetów branż okołobiznesowych ${ }^{45}$ : Elżbieta Zapendowska - ekspert od emisji głosu i względów technicznych, Jacek Cygan - autor największych polskich hitów, showman - Kuba Wojewódzki oraz dziennikarz muzyczny i znawca sektora fonografii - Robert Leszczyński. W ten oto sposób wylansowano gwiazdy pokroju: Krzysztofa Zalewskiego, Moniki Brodki, Macieja Silskiego, Ani Dąbrowskiej czy Tomka Makowieckiego. Jednakże - jak wskazuje Monika Brodka - był to jeden $\mathrm{z}$ pierwszych, w dodatku sprawnie przeprowadzonych programów, który docelowo zaradzić miał deficytowi rodzimych wokalistów. Według artystki kolejne tego typu produkcje to jawne oszustwo i nadprodukcja talentów w coraz bardziej inkluzywnej branży ${ }^{46}$.

Po ogromnym zainteresowaniu takim typem programów oraz tłumami chętnych na castingach, inni polscy nadawcy postanowili jednakże wbrew etyce iść za ciosem i także postawili na talent show, szczególnie muzyczne. Kilka lat później doszło do emisji Mam talent (z udziałem dzieci) i Fabryki gwiazd (połączenie reality i talent show), a następnie $X$ Factora, który także dorzucił swoje przysłowiowe trzy grosze do zasad, włączając: bootcamp, domy jurorskie czy eliminacje uczestników podczas etapu z gorącymi krzesłami. Potem lawinowo zaczęto produkować widowiska oparte na formacie - Must Be the Music, Śpiewaj i walcz, Bitwa na głosy czy The Voice of Poland. Rozpoczęły się również produkcje bazujące nie tylko na talencie wokalnym, lecz także: gotowaniu, tańcu czy sztuczkach cyrkowych, które autor określa w innej swojej publikacji jako formaty mieszane ${ }^{47}$. Konsekwencją zaprezentowanych widowisk była jednakże w największym stopniu wspomniana nadprodukcja talentów.

\section{Od spełnienia marzeń po nadprodukcje talentów - badania nad formatem na przykładzie wybranych widowisk muzycznych}

W celu weryfikacji wielu teorii i mitów narosłych wokół audycji tworzonych na zasadach formatu, szczególnie talent show, autor posłużył się technikami jakościowymi i ilościowymi, aby uzyskać efekt triangulacji i zapewnić eksperymentowi wysoką rangę naukową. Techniki jakościowe, jakie wykorzystano, to: wywiady z dwoma uczestnikami popularnych programów muzycznych, rozmowa ekspercka ze specjalistką branży rozrywkowej - Agatą Kuliś, oraz studium przypadku wybranych uczestników w obrębie wskazanych przez nich programów. Natomiast metodą ilościową była ankieta badawcza (PAPI i CAWI) skierowana do widzów tych widowisk w grupach

${ }^{45}$ A. Jupowicz-Ginalska, Jurorem być..., dz. cyt.

46 „Dziennik Zachodni”, Reaktywacja Idola..., dz. cyt.

47 Ł. Flak, Addytywność dziecięcych formatów rozrywkowych, „Zarządzanie Mediami” 2019, t. 7 , nr 3, s. 178-179. 
wiekowych $(16-24,25-40,41-65,65+)$. Autor poddał analizie dwa formaty, które postarał się zobrazować w obliczu zasad i mechanizmów rządzących w poszczególnym programie. Pierwszym formatem jest holenderski The Voice of Poland, a drugim brytyjski Must Be the Music. Programy te różnią się przede wszystkim profilem poszukiwania muzycznych autorytetów. W The Voice... szuka się najlepszego głosu w Polsce, natomiast w Must Be... - artystów tzw. gotowych, czyli przygotowanych do wejścia na polski rynek muzyczny ze swoimi autorskimi utworami.

\subsection{Must Be the Music}

Must Be the Music to program telewizji Polsat realizowany od 5 marca 2011 roku przez blisko 5 lat, którego wyemitowano aż 11 edycji, a na swojej stronie internetowej reklamował się jako „muzyczne show, które wypromowało kilkudziesięciu wykonawców" obecnych w większości rozgłośni w naszym kraju ${ }^{48}$. Sztandarowym wyróżnikiem był akcent na autorskie utwory, w mniejszym stopniu covery. Od początku obecni w panelu jurorów byli: legenda zespołu Manaam - Kora Jackowska, ekspert emisji głosu - Elżbieta Zapendowska oraz Adam Sztaba - dyrygent. W kilku pierwszych edycjach grono zasilił Wojciech Łozowski - frontman Afromental, następnie twarz muzyki alternatywnej w Polsce - Piotr Rogucki, którego w 11. edycji show zastąpił multiinstrumentalista, kompozytor i wokalista oraz twórca pojęcia „yass” (stylu w muzyce łączącego elementy współczesnej muzyki improwizowanej, jazzu, punk rocka i folku) - Tymon Tymański. Tu także wzorem Idola mieliśmy do czynienia m.in. ze spektaklem poniżania, który najczęściej wywoływała liderka Maanam, Kora. „Ja lubię inteligentnych ludzi, a ty jesteś po prostu durniem. Wracajcie, Los Angeles czeka na was" - rzekła do zespołu Nasty Crue w jednym z odcinków.

\subsection{The Voice of Poland}

The Voice of Poland to natomiast talent show stacji TVP od lat cieszący się olbrzymią renomą i popularnością, stworzony przez Johna de Mola, który we wrześniu 2010 roku zadebiutował na kanale holenderskiej stacji RTL4 jako The Voice of Holland. W tej chwili już ponad 50 państw na świecie kontynuuje format i wykupiło do niego licencję wraz z ustaleniami dotyczącymi adaptacji. Od początku promowany jako nieco inne talent show od reszty: „Tam, gdzie kończą się inne talent show, zaczyna się Voice of Poland”. Od początku show zaskoczył wszystkich samą formułą - czworo jurorów nie widzi śpiewającego uczestnika i odwracają się do niego tylko wtedy, gdy urzeknie ich swoim głosem. Na ten temat wypowiedziała się jurorka 7. edycji show - Natalia Kukulska ${ }^{49}$ :

${ }^{48}$ Profil poświęcony programowi MBTM, http://www.polsat.pl/program/tylko-muzyka-mustbe-the-music/ (dostęp: 30.05.2017).

${ }^{49} \mathrm{WP}$, „The Voice of Poland”: wielkie emocje i najlepsze głosy w Polsce!, https://teleshow.wp.pl/thevoice-of-poland-wielkie-emocje-i-najlepsze-glosy-w-polsce-6033674195567233a (dostęp: 4.06.2017). 
Dla mnie to było niesamowite przeżycie, żeby słuchać głosów, nie widząc osoby, i później być zaskoczoną tym, jak to kompletnie nie jest kompatybilne z fizis danej osoby i że ten głos jest tylko tym jedynym elementem, który ma zwrócić uwagę.

Blogerka Magdalena Stolarczyk krytycznie podchodzi jednak do tzw. przesłuchań w ciemno. Według blogerki to kłamstwo na potrzeby zareklamowania marki, jaką jest w każdym kraju The Voice of... Według kobiety właściwy udział poprzedza precasting, podczas którego ocenia się rozmaite walory uczestnika, łącznie z jego historią i poglądami. Ogółem, według opinii Stolarczyk, program przebiega według konkretnego scenariusza, a sama widownia w studiu jest zarządzana przez wyznaczoną osobę, mającą zapewnić widzowi przed odbiornikiem godziwy poziom rozrywki ${ }^{50}$.

\subsection{Wywiady pogłębione z uczestnikami show}

Podobnych treści, świadczących o instrumentalnym traktowaniu uczestników poszczególnych stacji, dostarczają historie uczestników przedstawionych wyżej formatów, które ze względu na wyraźne wskazanie rozmówców zostały zanonimizowane. Obaj uczestnicy wskazują na wieloetapowość talent show The Voice of Poland i Must Be the Music, polegającą na nagrywaniu dużo większej ilości materiału niż jest pokazywany w telewizji po to, by zmontować z tego jak najciekawszą historię dla widza. Uczestnik polsatowskiego show opowiada także o łączeniu uczestników niezależnie od ich woli, przytacza konkretne sytuacje, w których zespół stworzony zostaje za pośrednictwem ingerencji produkcji. Również dobór piosenek staje się tu nieadekwatny do tego, co jest pokazywane na szklanym ekranie. To produkcja decyduje, co można, a czego nie. Jeśli ktoś przychodzi z własną twórczością, musi udowodnić, że to się, mówiąc kolokwialnie, „sprzeda”. Rozmówca wspomina także o stałym monitorowaniu i reżyserowaniu show:

Od dobrych duchów programu usłyszałem, że w każdym talent show decydują ludzie odpowiadający za cały przebieg programu $\mathrm{z}$ wozu transmisyjnego.

Uczestnik podnosi temat wyboru repertuaru w trakcie uczestnictwa w Must Be the Music:

Jeśli chodzi o dobór repertuaru, to duży wpływ na to ma produkcja. Nawet jeśli ma się swoje piosenki. To nie jest tak, że my mamy ostateczną decyzję, jeśli chodzi o dobór repertuaru. Na każdym etapie dostawałem też mejla z propozycją covera. Z racji, że produkcja była zdania, że lepszy odzew będą miały piosenki, które ludzie już znają, w przeciwieństwie do idei show.

Na pytanie o stopień manipulacji w talent show, odpowiada:

${ }^{50}$ M. Stolarczyk, The Voice - kolejna edycja wielkiej ściemy, http://www.czytamiwiem.pl/ the-voice-of-poland-wielka-sciema/ (dostęp: 3.06.2017). 
Są pogłoski, że ogromny wpływ na czyjąś wygraną ma produkcja. Z perspektywy czasu uważam, że tak jest. Dla mnie duże znaczenie w głosowaniu mają też oceny jurorów, co jest takim trochę działaniem podprogowym.

Gdy mowa o The Voice of Poland, pytany potwierdza, iż każdy otrzymuje swoiste wskazówki dotyczące wyboru repertuaru:

Wybór piosenki na bitwę też wyglądał tak, że trener nam wybrał jakiś utwór, a produkcja nie zaakceptowała tego wyboru. Kazali nam śpiewać piosenkę maglowaną przez stacje radiowe. W nokaucie też musisz wybrać 20 piosenek, ja dostałem też tam piosenkę z szarego końca swojej listy.

Zapytany o ogólne zasady programu i powody atrakcyjności uczestników w widowisku, odpowiada natomiast:

W Voice... jest generalnie tak, że przesłuchuje cię czworo ludzi: pan redaktor, wydawca, ekspert wokalny itd. Wszystko, co napiszesz w ankiecie, rzutuje na to, czy cię wezmą czy nie. Potem sobie śpiewasz. Potem oni ci wysyłają mejl, że wstępnie zostałeś zaakceptowany. Ale to nie znaczy jeszcze, że będziesz w programie. Muszą ci wysłać wszystkie dokumenty do podpisania, czyli umowę na 18 stron. Musisz ją drukować kilka razy, wysyłać. A są takie sytuacje, że w ostatniej chwili potrafią ci napisać w stylu: „Sorry, ale jednak nie”. A ty wcześniej się na to nie nastawiasz. Natomiast jest to wszystko wytyczną tego, czy kamery cię lubią, czy masz historię, jak zaśpiewasz i czy wpasujesz się w ich odgórny scenariusz.

W wywiadzie z osobą mającą za sobą swój udział w formacie The Voice of Poland pada także kwestia wyboru zwycięzców, decyzyjności producentów i korzeni danego formatu:

Każdy w tym programie ma swój czas. Z tego, co wiem, oni robią tak, że wybierają sobie ludzi na precastingu, potem kolejna selekcja. Swoje wytyczne wysyłają do Holandii, wtedy Holendrzy ponoć już finalnie decydują.

W obu przypadkach mowa jest także o restrykcyjnej umowie z produkcjami widowisk, która pozwala podporządkowywać uczestnika decyzjom producenta. Jeden z uczestników mówi:

Większość takich rzeczy jest nagrywana wcześniej, ma scenariusz. (...) Jest także kara finansowa za ujawnienie tajemnic produkcji, w Voice... jest to chyba 50 tysięcy złotych.

Kolejnym ważnym aspektem jest los indywidualnego artysty w show. Na zadane przez autora pracy pytanie: Jak traktuje się indywidualnego uczestnika w programie i czy promuje się go wystarczająco podczas trwania programu?, padają odpowiedzi, iż jest spora promocja wykonawców, jednak sama umowa stanowi, że to nie przekłada się na zysk dla uczestnika, lecz bardziej dla stacji.

Zarówno uczestnik Must Be the Music, jak i występujący w The Voice of Poland jednoznacznie stwierdzają, że talent show służą maksymalizacji zysku, a ich główną konsekwencją jest nadprodukcja talentów: 
Talent show będą, dopóki będą z tego pieniądze. Wydaje mi się, że programy będą tylko ewoluować. (...) Co do samych uczestników część z nich wie, jak to się rozgrywa, część jest nieświadoma i dowiaduje się w trakcie. Nieprawdą jest, że każdy z nich znajdzie pracę marzeń. Po programie to już jest decyzja każdego z osobna, czy chce też w tym dalej uczestniczyć, to jest specyficzne środowisko.

Talent show to maszynka do robienia pieniędzy, a szczególnie nabijanie kasy do kieszeni produkcji. Na dobrą sprawę uczestnik z tego wyniesie bardzo niewiele. Nabawia się bardzo często depresji albo stanów lękowych. Fakt jest taki, że produkcja na tym wszystkim zarabia najbardziej. Jeśli ludzie to oglądają, głosują, nabijają mnóstwo hajsu produkcji. Uczestnicy są raczej potrzebni na chwilę, aby przyciągnąć uwagę, potem znikają z przestrzeni publicznej. To jest kompletną nieprawdą, że nawet sami zwycięzcy mają realną szansę zagościć w branży na dłużej - trzeba umieć się przebić, poza tym to bardzo złożony proces.

Przedstawiciele wybranych show dają świadectwo temu, iż telewizyjny przemysł rozrywkowy uwikłany jest w różnorodne restrykcje decydujące o losie uczestników. Słowa te potwierdzone zostają również w rozmowie z ekspertem branży rozrywkowej - wokalistką Agatą Kuliś.

\subsection{Rozmowa ekspercka}

Agata Kuliś na wstępie informuje, że są pozytywne i negatywne walory widowisk muzycznych w telewizji:

Jestem za wszelką edukacją muzyczną od najmłodszych lat, takie programy napędzają pewien trend i to jest pozytywne, szkoda natomiast, że stoi za tym głównie zysk.

Ekspertka porusza także aspekt utowarowiania człowieka i jego talentu w obliczu „blasku fleszy”:

Chcemy się pokazać, zaistnieć, kiedyś nie było to takie proste, teraz są talent show rozmaitej maści. Kariera jest na wyciągnięcie ręki, ale przemysł muzyczny, ogólnie rozrywka, rządzi się swoimi prawami - ponosimy pewien marginalny koszt za cenę sławy i spełnienia marzeń. Dajemy w zamian przede wszystkim swoje emocje, czasem bardzo wykreowane, eksponujemy swoją osobowość, dajemy zmieniać swój wizerunek, swoją historię życiową. Zauważmy, ile jest teraz w takich programach łzawych historii, nie dlatego, że ludzie sami chcą się tym dzielić, jest na to ogromny nacisk, to się po prostu dobrze sprzedaje i napędza oglądalność show.

Artystka wspomina także o nieodzownym elemencie talent show, czyli storytellingu:

Storytelling jest niezwykle istotnym elementem takich widowisk i moim zdaniem jedną $\mathrm{z}$ ważniejszych cech urastających do rangi samego talentu.

Według Kuliś najpoważniejszą konsekwencją formatów na przykładzie talent show, $\mathrm{z}$ akcentem na te muzyczne, jest nadprodukcja talentów, choć nieokreślona przez rozmówczynię tak dosłownie: 
Mamy wysyp programów, szczególnie muzycznych. Z jednej strony - krzewimy edukacje muzyczną i dajemy ludziom szansę na sukces, z drugiej - trochę oszukujemy tych ludzi. Na własnej skórze przekonałam się, jak specyficznym tworem jest sektor rozrywkowy i jakimi prawami się rządzi. Jeśli ktoś myśli, że potrafi śpiewać i sukces ma w kieszeni, nic bardziej mylnego. A trochę takiego przekonania nabiera się, oglądając wspomniane programy. Oszukuje się i widza, i takiego uczestnika. Produkuje się, brzydko mówiąc, setki czy tysiące takich artystów, dla których w takiej ilości miejsca na rynku po prostu nie ma i nie będzie. Program zarabia dobre pieniądze, a taki artysta potem musi sobie radzić, raz lepiej, raz gorzej.

\section{Zdaniem ekspertki niejednokrotnie los danego uczestnika można przewidzieć:}

Jeśli dobrze się przypatrzymy, łatwo można dostrzec już na początku programu jego potencjalnego zwycięzcę. (...) Osobiście odradzałabym udział w programach tego kalibru, no chyba, że ktoś to robi świadomie albo to pomysł wytwórni fonograficznej - często się to zdarza.

Jako główny powód produkowania programów na kanwie formatu Kuliś wymienia łatwy zysk ze sprawdzonych, dobrze obmyślanych programów:

Na pewno programy istnieją, bo jest na nie popyt, bo ludzie lubią tego typu rozrywkę. Część jest też realizowana na niezłym poziomie, inne na trochę gorszym, ale nadal widownia będzie je chętnie oglądać, bo to rozrywka za darmo w cudzysłowie. A uczestnicy, myślę, że każdy, kto zdradza jakiś talent, lubi śpiewać, nosi w sobie chęć posiadania grona słuchaczy, to jest chyba najszybsza droga.

Wywiad $\mathrm{z}$ ekspertem cenionym w środowisku muzycznym wprost świadczy więc o wysokim poziomie sterowalności widowiskiem w programach typu talent show. Artystka podnosi wiele kwestii, które pojawiały się również w rozmowach z uczestnikami show: storytelling, utowarowienie oraz redefinicja talentu. Przede wszystkim jednak potwierdza występowanie nadprodukcji talentów w widowiskach na bazie formatu jako najpoważniejszej konsekwencji ich produkowania.

\subsection{Raport z badania ilościowego}

Przytoczone opowieści to studium manipulacji, które świadczy o świadomej nadprodukcji uczestników motywowanej chęcią zysku. Aby sprawdzić świadomość na temat formatów i opinie widzów co do nadwyżki talentów, autor posłużył się metodą ilościową w postaci ankiety. Tym samym stworzono kwestionariusz ankiety zawierającej zestaw pytań odnośnie do talent show, m.in. o: częstotliwość oglądania show, rozpoznawalność uczestników i programy, z jakich pochodzili (Dawid Podsiadło, Margaret, Daria Zawiałow, Monika Brodka, Mateusz Grędziński czy Ada Szulc), piosenki wykonywane przez artystów zaczynających od udziału w formacie (np. Bądź duży, Nieznajomy), pseudonimy artystów show, kartę formatu oraz adekwatność liczby uczestników w tego typu widowiskach. 
Ankieta została przeprowadzona w pierwszej połowie 2017 roku za pośrednictwem: PAPI oraz CAWI, przy użyciu stron internetowych (portale społecznościowe, fora, fanpagee talent show) oraz w kontakcie osobistym na próbie incydentalnej w łącznej liczbie 203 osób w systemie doboru ochotniczego. Należy jednak wyraźnie zaznaczyć, iż z powodu specyfiki badanego środowiska kryterium ilościowe jest niezwykle trudne w ujęciu, choćby ze względu na użyty dobór próby czy wypreparowanie konkretnego operatu losowania i wyłonienie reprezentacji - widownia tego typu produkcji jest niezwykle zmienna, zaś wszelkie badania telemetryczne są zazwyczaj prowadzone w kontekście programów rozrywkowych ogółem lub talent show nie tylko muzycznych. Próba ta pozwala więc na zasygnalizowanie pewnego trendu, jednakże nie stanowi podstaw do generalizacji zjawisk w podanych grupach wiekowych (ogranicza się wyłącznie do ankietowanych 203 osób). Tak ujęte badanie ilościowe można potraktować więc jako wstęp (pilotaż) do szeroko zakrojonych i wymagających większej rzetelności metodologicznej badań.

Ogółem w przeprowadzonej ankiecie wzięło udział 76,8\% (155 - n) kobiet i $23,2 \%(48-n)$ mężczyzn, reprezentujących grupy wiekowe: 16,24, 25-40, 41-65, $65+$ oraz wykształcenie: wyższe, średnie, zasadnicze, gimnazjalne i podstawowe. Trzy pierwsze grupy wiekowe wypowiedziały się za pośrednictwem ankiety umieszczonej w Internecie. Grupa wiekowa 65+ została jednakże ankietowana poprzez PAPI, czyli wywiad bezpośredni, realizowany przy użyciu papierowej ankiety wypełnianej przez autora pracy przy danym ankietowanym ze względu na utrudnione kryterium dotarcia do badanych.

Według przeprowadzonych badań programy muzyczne na kanwie formatu cieszą się niemałą popularnością (wykres 2). Spośród ankietowanych można wyróżnić dwie dominujące grupy: pierwszą - entuzjastów jednego formatu oglądających każdy jego odcinek - 33,5\%, czyli (68 - n), drugą - osoby oglądające tego typu produkcje dość sporadycznie - 32,5\%, czyli $(66-\mathrm{n})$.

Wykres 2. Częstotliwość oglądania muzycznych talent show

\section{JAK CZĘSTO OGLĄDA PAN/PANI MUZYCZNE TALENT SHOW?}

ـ Oglądam wybrane show sporadycznie

n Od czasu do czasu włączę jakiś muzyczny program

- Oglądam wszystkie muzyczne show

- Mam swoje wybrane talent show i oglądam każdy odcinek

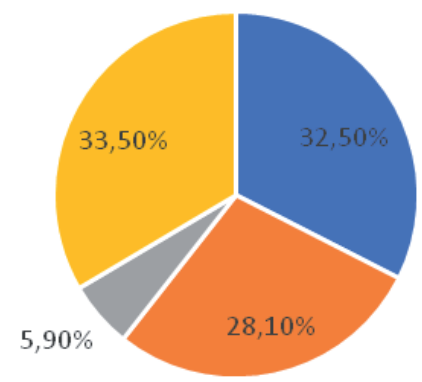

Źródło: badania własne. 
Według $(203-\mathrm{n})$ ankietowanych w pytaniu wielokrotnego wyboru zdecydowanym faworytem spośród podanych talent show okazał się program The Voice of Poland (wykres 3). Wskazano go aż 111 razy, co stanowi 28\% wszystkich wskazań (łącznie w liczbie 397). Na drugiej pozycji program Mam talent - 95 wskazań. Na ostatnim miejscu podium znalazł się program Must Be the Music, który wskazano 67 razy, co stanowi 17\% wszystkich wskazań show w podanym pytaniu.

Wykres 3. Najczęściej oglądane muzyczne talent show

KTÓRE PROGRAMY OGLĄDA PAN/PANI NAJCHĘTNIEJ?

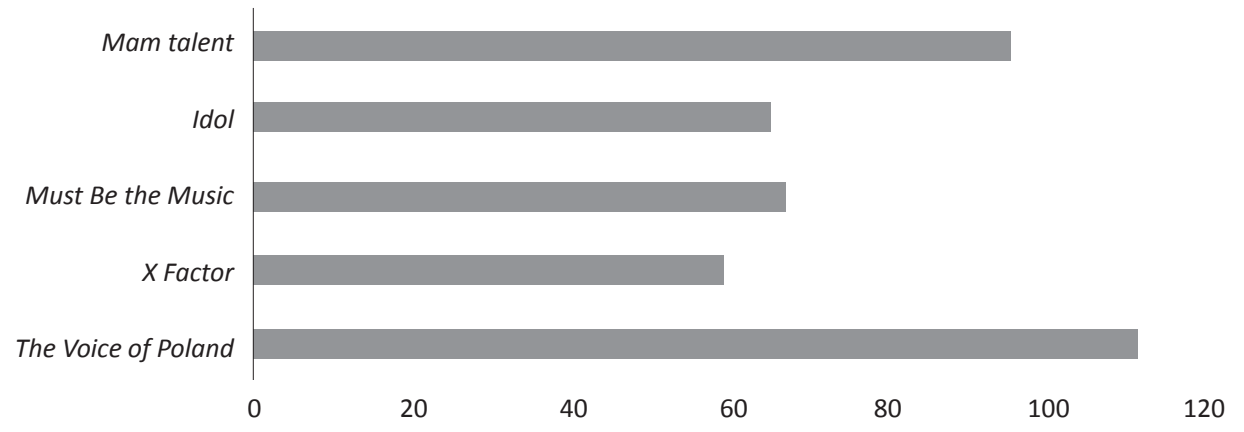

Źródło: badania własne.

Z przeprowadzonej ankiety wyniknęło ogółem, iż żadna z badanych grup wiekowych nie posiada $w$ pełni rozwiniętego aparatu wiedzy na temat formatów (100\% ankietowanych [203 - n osób] nie udzieliło w pełni poprawnej odpowiedzi na pytanie o kartę formatu), jednakże kluczową sprawą okazał się odbiór uczestników w widowiskach. Ankietowani przyznają, iż mamy obecnie do czynienia ze zbyt dużą liczbą i uczestników, i widowisk tego typu. Sami także nie potrafią rozpoznać większości z nich po pseudonimie artystycznym oraz przyporządkować piosenki do artysty. W pytaniach otwartych duża większość rezultatów oznacza brak prawidłowej odpowiedzi na zadane pytanie. Przykładowo: przy pytaniu, do kogo należy pseudonim „Dziarma”, padają odpowiedzi: „nie wiem”, „nie znam”, „kto to?” czy „Chylińska?”. Stanowią one aż (178 - n, czyli 79,8\% ankietowanych, natomiast pseudonim „Rudy” rozwikłało zaledwie (20 - n), co stanowi 9,9\% badanych.

Badanie ilościowe (w kontekście wybranej próby) podnosi jednoznacznie, iż wokół formatów rozrywkowych mamy do czynienia $\mathrm{z}$ szeregiem negatywnych czynników, przede wszystkim z nadprodukcją talentów. Jedno z ostatnich pytań wykazuje motywy powstawania widowisk tego typu: zarabianie dużych sum pieniędzy - tzw. maszynka do zarabiania pieniędzy [(101 - n), co stanowi 49,8\% ogółu badanych] - i efektowna promocja stacji [15,3\% ogółu badanych, czyli $(31-n)]$, 
wskazując również w mniejszej części na pozytywne cechy show jako „kuźni nieodkrytych talentów" [(51 - n), stanowiąc 25\% wszystkich ankietowanych] (wykres 4).

Wykres 4. Definicja talent show w opinii ankietowanych

\section{KTÓRY TERMIN NAJTRAFNIEJ DEFINIUJE WED $Ł$ G PANA/PANI PROGRAM TYPU TALENT SHOW?}

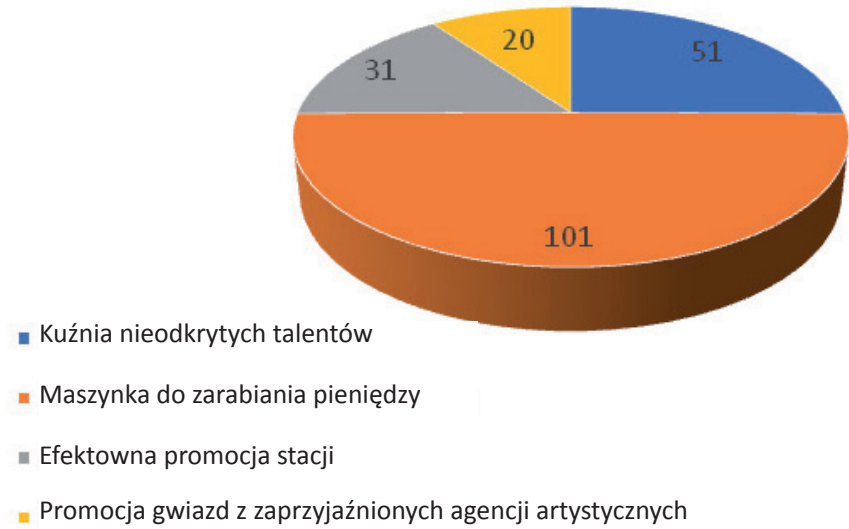

Źródło: badania własne

\subsection{1. Świadomość ankietowanych dotycząca mechanizmów rządzących talent show w poszczególnych grupach wiekowych}

Najbardziej świadomą grupą są badani w przedziale wiekowym 16-25, którzy uważają, że wszystkie zabiegi show są przeliczane na złotówki, jednakże nie kojarzą ani biblii formatu, ani dokładnych zasad zarządzania takimi programami. Ta grupa wykazuje się jednak sporą znajomością wybranych uczestników.

Badani w przedziale wiekowym 26-40 są za to bardziej lojalni wobec konkretnych programów i to im poświęcają uwagę. Także sądzą, że za takimi produkcjami kryją się pieniądze, ale nie znają mechanizmów służących monetyzacji mediów. Jednocześnie twierdzą także, iż programów tego typu jest za dużo, a uczestnicy stanowią dla nich tylko tło.

Respondenci w przedziale 41-65 lat są natomiast widownią ulegającą manipulacji w dużo większej skali. To osoby biorące często udział w głosowaniach, nieznające relacji między uczestnikami a pracownikami show oraz niepotrafiący wskazać osób, które w ostatnim czasie brały w takich widowiskach udział. Myślą, że decyzje podejmują jurorzy, a piosenki w programach muzycznych uczestnicy dobierają sami. Nie znają także pojęcia formatu, zaś o „biblii formatu” nigdy nie słyszeli.

Najmniejszą świadomość mają natomiast ankietowani w grupie 65+, która to, co słyszy i widzi w mediach, uznaje za nieregulowany przekaz medialny. To grupa 
wiekowa wierząca w rzetelność i uczciwość dziennikarzy, a główną cechą, jakiej oczekuje od mediów, jest funkcja informacyjna. Tacy odbiorcy korzystają także z mediów sformatowanych pod ich poglądy i przynależność partyjną. Oglądając telewizję, często mylą ją z rzeczywistością, opowiadając historie ze szklanego ekranu jak fakty z życia.

\subsection{Wnioski z badań empirycznych}

Dzięki zastosowanej triangulacji metod - połączeniu pogłębionych wywiadów z uczestnikami i ekspertem, analizy ich historii w programie oraz ankiet wśród różnorodnych przedstawicieli społeczeństwa (choć ankiety same w sobie nie mogą być podstawą generalizacji wedle wybranej próby), autor potwierdził zakres przedstawionych wcześniej zjawisk i trendów obecnych w formatach rozrywkowych oraz wpływu posiadanej wiedzy na odbiór przekazu i jego modyfikacje. Okazało się także - zgodnie ze stawianymi hipotezami badawczymi, iż najpoważniejszą konsekwencją widowisk na kanwie formatu stała się nadprodukcja talentów, której są świadomi także widzowie, niepoddający jej jednak głębszej refleksji. Natomiast sami uczestnicy popularnych widowisk traktują ją zazwyczaj jako oczywiste ryzyko udziału i są świadomi kosztu marginalnego (potwierdza to także ekspert), jaki będą musieli ponieść za cenę spełnienia marzeń. Opowiadają także o licznych procesach i konsekwencjach programów tego typu oraz o braku empatii w stosunku do uczestników, jednakże uznają niektóre $\mathrm{z}$ nich na zbyt pikantne do publikacji, decydują się także nie występować pod swoim nazwiskiem ze względu na ostracyzm środowiskowy oraz kary finansowe wynikające z zawartych umów w programach.

\section{Podsumowanie: lean manufacturing a telewizyjny przemysł rozrywkowy}

Zgromadzony materiał empiryczny wykazuje, że prognozy przedstawione w obszernej literaturze (naukowej i publicystycznej), dotyczącej fabryki produkowania chwilowych „maskotek” stacji w postaci uczestników, zaczynają się sprawdzać.

Negatywne konsekwencje maksymalizacji zysku z widowisk typu talent show można jednakże w znacznym stopniu ograniczyć. Na podstawie sukcesu fabryki Toyoty, związanego z wdrożeniem zasad koncepcji lean manufacturing, autor proponuje podobne rozwiązanie dla środowiska telewizyjnego, oparte na: zaangażowaniu zasobów, nieustannym eliminowaniu wszelkiego marnotrawstwa oraz ciągłym doskonaleniu.

$\mathrm{W}$ wyniku takich wdrożeń japońska firma była bowiem w stanie produkować najwyższej jakości auta, zużywając znacznie mniej zasobów (materiałów, energii, czasu pracy ludzi i maszyn, wykorzystywanej powierzchni produkcyjnej i magazynowej) niż jej konkurenci. Było to możliwe przede wszystkim dzięki 
wyeliminowaniu marnotrawstwa, czyli tych wszystkich czynności, które nie dodawały wartości w oczach klienta. Marnotrawstwem według koncepcji lean manufacturing jest każda działalność ludzka, angażująca zasoby, lecz niewnosząca żadnej wartości określanej jako muda, na którą składa się siedem strat, zaś kluczowymi i najważniejszymi spośród nich są: nadprodukcja i niewykorzystany potencjał pracowników ${ }^{51}$.

W kontekście tematu talent show słuszne wydaje się zastosowanie wybranych zasad wzorem przytoczonego wyżej przykładu ${ }^{52}$ :

1) System ciągniony (ang. pull) - zasada twierdząca, że produkt lub usługa powinny być dostarczane klientowi dokładnie wtedy, kiedy są potrzebne, i dokładnie w takiej ilości, w jakiej są potrzebne. W ten sposób można ograniczyć liczbę rodzajów widowisk w danej ramówce. Istotny mógłby być także roczny zakaz występowania $\mathrm{w}$ innym formacie oraz kolejnej odsłonie tego samego show pokroju rocznego zakazu konkurencji.

2) Ciągłe doskonalenie (jap. kaizen) - japońska filozofia polegająca na systematycznym, dosłownie codziennym wdrażaniu, często drobnych udoskonaleń oraz usprawnień jako nieodłącznego elementu lean management, zgodnie z którym procesy ciągłego doskonalenia nigdy się nie kończą. Odnosząc się do przykładów z talent show, dobrym rozwiązaniem mogłoby się okazać zamykanie uczestników tego typu produkcji w akademiach szkolenia umiejętności wokalnych, scenicznych na wzór Fabryki gwiazd, lecz z wyeliminowaniem elementów reality show, które najprawdopodobniej zdecydowały o porażce rynkowej widowiska. Taki proces doskonalenia mógłby być także dokumentowany i pokazywany na końcu przygody z programem każdego z uczestników.

3) Zarządzanie wynikami (ang. performance management) - jako akcentowanie systematycznego pomiaru, analizy i poprawy osiąganych wyników. Talent show, zamiast zapraszać „absolwentów” na gościnne występy w aż tak dużej liczbie, mogłoby tworzyć: rankingi sprzedaży płyt, współpracy z wytwórniami, analizy losów uczestników, oczywiście do wglądu na ich stronach oraz fanpageach w social mediach. Powinny się uczyć w ten sposób na swoich błędach i liczyć przy tym na feedback ze strony otoczenia.

4) Łatwość i prostota - oparte na założeniu, iż złożoność zwiększa koszty oraz jest przyczyną wielu błędów. Talent show mogłoby ograniczyć liczbę etapów - bitwy, nokauty, bootcamp jako działalności zwiększające stres uczestników oraz stawiające ich w relacji kłusownik-zwierzyna. Dla widzów to także mało korzystny zabieg z racji zbytniej zawiłości etapów show. Przykładem mogą być „cross-bitwy” 5. edycji The Voice of Poland, które w obliczu polskich praktyk kulturowych kompletnie się nie przyjęły.

51 J.P. Womack, D.T. Jones, D. Roos, Maszyna, która zmieniła świat, Prodpress, Wrocław 2008.

52 A. Grycuk, Lean Government, czyli koncepcja szczupłego zarządzania w administracji publicz$n e j$, ,Analizy BAS” 2011, nr 3 (47), s. 4-6. 
5) Współpraca z partnerami zewnętrznymi - jako istotny element filozofii lean oparty na współpracy z partnerami pomocniczymi. Programy talent show mogłyby nawiązać współpracę z rozgłośniami radiowymi wzorem Must Be the Music (w polsatowskim show RMF FM zapewniał promocję singla artystom). Kluczowe mogłyby być także kontrakty z autorami tekstów i opieka więcej niż jednej wytwórni płytowej w danej edycji show. Coś podobnego zaczął od kilku edycji kultywować The Voice of Poland, prezentując single finalistów przygotowywane z profesjonalistami, publikowane w serwisach streamingowych zaraz po odcinku finałowym.

Koncept ten jest jednakże przykładem możliwości ograniczenia negatywnych konsekwencji związanych z produkcją widowisk na kanwie formatu i stanowi jedynie makietę inspiracji, a nie receptę gotową do wdrożenia w obrębie widowisk telewizyjnych. Należałoby zdecydowanie poddać pomysł ocenie ekspertów z branż: prawnej, rozrywkowej, zarządzania zasobami, szczególnie pod kątem etyki. Należałoby również liczyć się z faktem, iż w przypadku zastosowania karty formatu takie kwestie podlegałyby również konsultacjom na szczeblu międzynarodowym - z właścicielami formatu. Przed wdrożeniem powinno się przeprowadzić analizę ryzyka i zabezpieczyć alternatywne ścieżki rozwiązań. Głównie dlatego, że tego typu mechanizmy mogłyby pomóc, ale mogłyby też skończyć się niepowodzeniem - w zależności od danego kręgu kulturowego oraz od wielu innych czynników.

Powyższe pomysły, nawet jeśli okazałyby się trafne, nie zlikwidowałyby całkowicie procesu nadprodukcji talentów, z pewnością jednak znacznie by go ograniczyły. Niewiadoma jest kwestia, czy i w jakim stopniu twórcy formatów (oraz zapożyczające je stacje telewizyjne) byliby tym rozwiązaniem zainteresowani i czy mogliby zrezygnować z części zysku dla dobra uczestników oraz ze względu na wzorce kulturowe i etyczne? Pewne jest natomiast, iż zjawisko nadprodukcji talentów (jak wykazały badania) urosło już do rangi ponadnarodowego problemu, będącego nieuchronną konsekwencją produkowania widowisk na bazie formatu.

\section{Bibliografia}

Anonim, Droga do gwiazd, http://zloteprzeboje.tuba.pl/zloteprzeboje/56,101972,8903277,dro ga-do-gwiazd-twoja-droga-dogwiazd,,2.html (dostęp: 27.05.2019).

Barta J., Markiewicz M., Prawo autorskie, Wolters Kluwer, Warszawa 2010.

Burn A., Parker D., Analysing Media Texts, Bloomsbury Academic, London-New York 2003.

Cury I., Directing and Producing for Television: A Format Approach, Focal Press, Amsterdam 2007.

Casetti F., Odin R., Od paleo- do neotelewizji. W perspektywie semiopragmatyki, [w:] A. Gwóźdź (red.), Po kinie? Audiowizualność w epoce przekaźników elektronicznych, Universitas, Kraków 1994.

Czernecka G., Top Model Polska 6 - Patryk Grudowicz już ma nowy uśmiech!, https://www.gala. $\mathrm{pl} /$ artykul/top-model-polska-6-patryk-grudowicz-ma-nowy-usmiech-161111102437 (dostęp: 3.01.2019).

Czym jest talent?, https:/hrht.pl/czym-jest-talent/ (dostęp: 30.12.2018). 
Delon M., Introduction, Édition Gallimard: Bibliothèque de la Pléiade, Paris 1990.

De Sade M., Histoire de Juliette, Rome 1797.

„Dziennik Zachodni”, Reaktywacja Idola? To nadprodukcja talentów!, https://tiny.pl/t9dpc (dostęp: 13.12.2018).

Faktor Ałty Pugaczow, https://dziendobry.tvn.pl/a/faktor-ally-pugaczowej (dostęp: 31.12.2018).

Flak Ł., Addytywność dziecięcych formatów rozrywkowych, „Zarządzanie Mediami” 2019, t. 7, nr 3.

Flak Ł., Zarządzanie wizerunkiem uczestników muzycznych talent show na wybranych przykładach (praca magisterska niepublikowana), Kraków 2017.

Grycuk A., Lean Government, czyli koncepcja szczupłego zarządzania w administracji publicz$n e j$, „Analizy BAS” 2011, nr 3 (47).

Jabłońska B., Dziecko - media - muzyka: fenomen muzycznych TV talent show, [w:] M. Bogunia-Borowska (red.), Współczesny świat dziecka. Media i konsumpcja, Wydawnictwo Uniwersytetu Jagiellońskiego, Kraków 2019.

Jupowicz-Ginalska A., Jurorem być, czyli rzecz o komisjach sędziowskich w programach talent show, „Rocznik Bibliologiczno-Prasoznawczy” 2012, nr 4 (15), z. 2.

Kreft J., W luce stabilności - poszukiwanie modelu biznesu starych mediów w cyfrowym środowisku, [w:] B. Nierenberg (red.), Zarządzanie reklama, Wydawnictwo Uniwersytetu Jagiellońskiego, Kraków 2015.

Medioskop, Format telewizyjny, https://tiny.pl/t9cnb (dostęp: 30.12.2018).

Mikucki J., Format programu telewizyjnego a normy kulturowe. Przypadek reality show Rolnik szuka żony, „Naukowy Przegląd Dziennikarski” 2016, nr 1.

Misiło P., O etyce $w$ polskich mediach - ethics mortuus, http://www.misilo.pl/images/pdf/ Etyka_w_polskich_mediach_ethics_mortuus.pdf (odczyt: 31.12.2019).

Moran A., Copycat Television: Globalization, Program Formats and Cultural Identity, Luton University Press, Luton 1998.

Moran A., Malbon J., Understanding the Global TV Format, Intellect Ltd., Portland 2006.

Mrozowski M., Spectator in spectaculum. Ukryte osobowości programów telewizyjnych TVP1, TVP2, TVN, Polsat, „Studia Medioznawcze” 2010, nr 1 (40).

Niesłony K., Kultura polskiej twórczości audiowizualnej w tworzeniu krajowych adaptacji zagranicznych formatów telewizyjnych, „Pismo Humanistyczne” 2015, z. XIII.

Nowakowski P.T., Fast food dla mózgu, czyli telewizja i okolice, Maternus Media, Tychy 2002.

Ogonowska A., Edukacja medialna: ziemia wciąż nieznana?, „Kultura, Społeczeństwo, Edukacja” 2012, nr 1.

Orłowski T., Jak działaja media - na przykładzie talent-show. TAK jestem na Nie, http://linkd. $\mathrm{pl} / \mathrm{kk} 9$ (dostęp: 10.08.2019).

Perkowska K., Problemy produkcji telewizyjnych formatów na podstawie przykładów audycji zrealizowanych $w$ Polsce, niepublikowana praca magisterska, dostępna w bibliotece PWSFTViT, Łódź 2012.

Pinkalski Z., Prawna ochrona formatów telewizyjnych, Wolters Kluwer, Kraków 2015.

Profil poświęcony programowi MBTM, http://www.polsat.pl/program/tylko-muzyka-mustbe-the-music/ (dostęp: 30.05.2017).

Przylipiak M., U źródeł reality show, „Słupskie Prace Filologiczne. Seria Filologia Polska” 2004, nr 3.

Ptaszek G., W stronę bezgatunkowości mediów? O funkcji gatunków medialnych w procesie odbioru, [w:] W. Godzic, A. Kozieł, J. Szylko-Kwas (red.), Gatunki i formaty we współczesnych mediach, Poltext, Kraków 2015.

Regulamin konkursu organizowanego w ramach audycji Top Model - sezon 7, https://cutt.ly/ hwuoLBV (dostęp: 26.07.2019). 
Słowniczek TVN, https://www.tvnmedia.pl/poradnik/slowniczek?tab=16 (odczyt: 1.07.2019).

Sroka W., Rajca M., Ochrona tajemnicy przedsiębiorstwa na przykładzie formatu telewizyjnego. Wybrane zagadnienia, „Studenckie Zeszyty Naukowe” 2017, vol. XX, nr 34.

Stolarczyk M., The Voice - kolejna edycja wielkiej ściemy, http://www.czytamiwiem.pl/thevoice-of-poland-wielka-sciema/ (dostęp: 3.06.2017).

Strinati D., Wprowadzenie do kultury popularnej, tłum. W.J. Burszta, Zysk i S-ka, Poznań 1998.

Szczygieł M., Projekt: Prawda, Fundacja Instytutu Reportażu, Warszawa 2016.

Wawer M., Przemiany modelu handlu formatami telewizyjnymi w wymiarze kulturowym i ekonomicznym, „Zarządzanie Mediami” 2020, t. 8, nr 1.

Womack J.P., Jones D.T., Lean thinking - szczupłe myślenie. Eliminowanie marnotrawstwa i tworzenie wartości w przedsiębiorstwie, Prodpress, Wrocław 2008.

Womack J.P., Jones D.T., Roos D., Maszyna, która zmieniła świat, Prodpress, Wrocław 2008.

Woźniak U., Przyjemność „instant” w formatach rozrywkowych z perspektywy procesów poznawczych i emocjonalnych, „Annales Universitatis Paedagogicae Cracoviensis: Studia de Cultura" 2013, vol. V.

WP, „The Voice of Poland”: wielkie emocje i najlepsze głosy w Polsce!, https://teleshow.wp.pl/ the-voice-of-poland-wielkie-emocje-i-najlepsze-glosy-w-polsce-6033674195567233a (dostęp: 4.06.2017).

Załucki M., Licencja na u̇̇ywanie znaku towarowego. Studium prawnoporównawcze, Oficyna, Warszawa 2008. 